\title{
Evaluating ICT adoption in rural Brazil: a quantitative analysis of telecenters as agents of social change [1]
}

\author{
Paola Prado \\ Roger Williams University \\ Mauro A Câmara \\ Faculdade Pitágoras \\ Marco A. Figueiredo \\ Loyola University Maryland
}

\begin{abstract}
This quantitative study surveyed 538 adults in isolated rural settings in the state of Minas Gerais, Brazil, to examine whether telecenters operated by the nonprofit organization Gems of the Earth improve digital literacy and promote social change. Using multivariate logistic regression, the study examined how individuals use information and communication technologies (ICTs) at the telecenter, and tested for predictors of their use. The findings confirm that these rural communities use ICTs for entertainment, to engage in civic participation, and to practice professional skills. The findings suggest that digital inclusion impacts these isolated communities by creating opportunities that may foster human development.
\end{abstract}

Keywords: Community informatics, Telecenters, Information and communication technologies, ICT4D, Digital inclusion, Digital divide 
Following the Declaration of Principles and a Plan of Action adopted at the 2003 World Summit of the Information Society, a number of Latin American nations have sought to meet Millennium Development Goals of digital inclusion through initiatives that promote universal access policies and facilitate the creation of community technology centers, or telecenters, where public access to ICTs is made available to less privileged communities at minimal cost or free of charge (International Telecommunications Union [ITU], 2003). Telecenters have been defined as public spaces that provide access to communication and information technologies that range from telephone connections and other office equipment such as facsimiles, to Internet-enabled computers (Proenza, Bastidas-Buch, \& Montero, 2001).

Whereas the sustainability and long-term viability of telecenters is often measured against pre-determined benchmarks, such as the number of computer users and jobs created as a result of workforce training programs (Eastin \& LaRose, 2000; GumucioDagron, 2003; Gurstein, 2003; Whyte, 1999; Whyte, 2000), development communication scholars who adhere to a participatory approach realize that community perceptions of social change form an integral part of any diffusion of innovation. In a similar manner, community informatics researchers are increasingly considering the role played by face-to-face interactions, cultural production, community values, behaviors, and the socially-relevant context within which individuals adopt the use of ICTs (Norris, 2001; Servon, 2002). As the discipline evolves, more studies are needed to understand how ICT tools are adopted, rather than why.

The present study replicates methods previously used to evaluate telecenter adoption in rural areas of the Caribbean to analyze the diffusion of information and communication technologies (ICTs) in one such remote area. It examines how two small rural mountain communities in Minas Gerais, Brazil, adopted ICTs made available by the Gemas da Terra (Gems of the Earth) non-profit network of telecenters, and in what ways their use of this innovation improved digital literacy, helped bridge the digital divide, and promoted positive social change. It begins by briefly recapping prior research on Latin American telecenters, their mission to foster digital inclusion, and the state of ICT adoption in Brazil, the focus of this special issue. Next, it describes the non-profit telecenter network examined in this case study. It then proposes an alternative conceptual model for telecenter evaluation, expanding the definition of effectiveness beyond technologically deterministic metrics of digital literacy and competence to include contextually-relevant, self-defined reports on how individuals use ICTs. Lastly, it analyzes survey results and discusses community perceptions of telecenter impact in the remote rural communities where the study took place.

\section{Telecenters and Digital Inclusion}

Throughout Latin America, the number of telecenters continues to grow exponentially since the first such public access facilities opened in the late 1990s, yet there is scant empirical evidence to indicate that their existence promotes digital inclusion in the communities they serve. Case studies and anecdotal evidence recorded at telecenter operations in the region have yet to yield, from a development communication perspective, comprehensive empirical findings about how ICTs are being adopted at 
telecenters in these countries. Still, a growing body of research that charts the evolution of telecenters in Brazil (Bossio, 2006; Sorj, 2001; Sorj, 2003), Colombia (Amariles, Paz, Russell, \& Johnson, 2006; Parkinson \& Lauzon, 2008; Parkinson \& Ramirez, 2006; Vallejo Montoya, 2007), the Dominican Republic (Granqvist, 2005; Prado, 2009), Mexico (Robertson, 1998), and Peru (Heeks \& León, 2009) examines how ICT access impacts social justice and human development. The latter line of research has yielded evidence about the different ways in which ICTs are being used at the telecenters, yet further study is needed to determine whether the reduction of digital poverty positively impacts communal prosperity, systemic inequality, and human well-being.

\section{ICT Adoption in Brazil}

In Brazil, more than one-third (39.2\%) of the population enjoyed Internet access in 2009 (ITU, 2010). While $23.85 \%$ of households claimed to have access to the Internet, only $5.92 \%$ had broadband connectivity (ITU, 2010). Mobile broadband users accounted for $4.47 \%$ of the population (ITU, 2010). Internet reach in the country surpassed that of every major nation in the Southern Cone, ahead of neighboring Chile (32.5\%), which adopted universal access policies ahead of Brazil, and Argentina, where less than one-third $(28.1 \%)$ of the population is online, despite slightly higher rates of broadband penetration (8\% ) (ITU, 2010). The rate of Internet access in Brazil more closely compares to that of its Andean neighbor Colombia, where $38.5 \%$ of the population is online (ITU, 2010).

Several agencies of the Brazilian government have enacted universal digital inclusion policies as part of a three-fold national strategy that encourages adoption of personal computers, promotes universal access in public schools, and establishes public ICT access points (Mori \& Assumpção, 2007). Yet, given the vast geographical distances in the expansive Brazilian territory, sparsely populated, less privileged rural communities barely register in the national geopolitical map and remain, for the most part, isolated from global trends and far removed from government action and support. In one such area of Brazil, nestled in the mountainous state of Minas Gerais, a group of rural localities was among the first to break the chain of isolation with the establishment of a non-profit network of telecenters which have made it feasible for those communities to access the Information Society.

\section{The Gems of the Earth Telecenter Network}

The Gems of the Earth Rural Community Telecenter Network was established as a Brazilian non-government organization (NGO) in September 2003 to facilitate the formation and operation of telecenters in small Brazilian rural communities of less than 2,500 inhabitants. The mission of the NGO is to empower isolated rural communities through the use of ICTs in order to promote social and economic development through the integration of the population into the Information Society (Figueiredo, Camara, and Sabin, 2006).

Prior to the creation of the NGO, a pilot project was incubated over a period of two years with the assistance of FUNIVALE, itself a long-established NGO that operates in one of the poorest areas of the Brazilian Northeast, the Jequitinhonha Valley. This period of research and development served to identify an appropriate methodology to 
deploy community telecenters in remote rural communities of the country (Figueiredo, 2005). Following that period, the Gems of the Earth NGO set up headquarters in Belo Horizonte, the capital of the state of Minas Gerais, where it established a telecenter network linking the rural communities of Conselheiro Mata, Milho Verde, Rodeador, São Gonçalo do Rio das Pedras, and Tombadouro.

Except for Rodeador, which sits at the base of the Backbone Range (Serra do Espinhaço), the communities are located at the top of the mountain range, more than a thousand meters above sea level. This region hosts the springs that converge to form the Jequitinhonha and Velhas rivers. Conselheiro Mata, Rodeador, and Tombadouro are in the Velhas river basin. Milho Verde and São Gonçalo do Rio das Pedras are located in the Jequitinhonha river basin. This region of the state is renowned for the mining of gold and precious stones that dates back to the late seventeenth century. The vast riches that flowed from this area to the Portuguese Crown placed it among the wealthiest areas of Brazil until the twentieth century, when mining yields subsided. Nowadays, gold, diamonds, and other precious stones no longer abound and the region is primarily known for its historical traditions. The rural communities that host the Gems of the Earth network were established during the gold rush and remain to this day bastions of mineiro [2] culture.

Each of these communities stands as a rural district adjoining a nearby urban area. Geopolitically, they belong to the municipalities of Datas, Diamantina, Monjolos, and Serro. They are connected to the urban centers through an average of 30 kilometers of unpaved roads that can be reached in a one-hour long drive. For the most part, the communities lack direct representation in local government, unless one of their members is elected to the council of representatives of their respective municipality. A number of regional, national, and global civil society organizations are represented in the communities, among them FUNIVALE, the San Francis of Assisi Association, and the Christian Fund. There are also local community associations.

The Gems of the Earth telecenters are being hosted in their respective community associations as an incubation project. Each community association provides the room for the telecenter and pays for utilities such as electricity and water. Each telecenter is equipped with at least two computers, a multi-function unit providing printer, copier, scanner and fax, and broadband Internet access via satellite, which the community gets to use at a nominal fee. The telecenters do not offer digital literacy training programs or structured activities of any sort. Instead, it is up to those individuals in the community who know how to use the Internet to coach others. As an incentive, those who volunteer their time to train peers get to use the facilities free of charge.

As the telecenters grow in community support and resources to serve the community, they are expected to become a separate NGO, directly associated with the Gems of the Earth Network NGO, whose assembly that selects its steering and fiscal committees are composed of the elected presidents of the telecenter NGO of each of the communities. This model provides for direct representation of the communities in the affairs of the telecenter network organization.

The two communities which provide the setting for this study share a past rich in culture and tradition in a remote mountain terrain populated largely by agricultural 
workers descended from African slaves who once worked the mines and tended the fields in the region's formerly vibrant extractive industry. In the years since the decline of mining, and until the relatively recent advent of telephony and Internet connectivity, these communities subsisted in isolation from outside markets and existed to a large extent beyond the daily reach of government services. Their location atop a mountain range that lies beyond major commercial transportation routes perpetuated longstanding patterns of social exclusion and limited opportunities for development. They thus provide a privileged setting in which to examine the impact of digital inclusion in promoting social change.

\section{Milho Verde}

Milho Verde is located an estimated five kilometers from São Gonçalo do Rio das Pedras, a rural locality that is also part of the Gems of the Earth network. The two communities sit between the historic cities of Serro and Diamantina, in what is known as the Estrada Real [3], or Royal Road, the major transportation link that connected the center of the mining region to Rio de Janeiro, which was the capital of Brazil during the years of the gold rush. Milho Verde's ties to Brazil's mining history draws a profitable tourist trade and positions the area as a favored site for vacation homes in the state of Minas Gerais.

\section{Tombadouro}

The community of Tombadouro is located 50 kilometers from São Gonçalo do Rio das Pedras. The community is well organized around a group of rural workers who run a farming cooperative responsible for meeting most of the community's food needs and markets surplus crops outside the area. Members of the cooperative constructed most of the homes and buildings in Tombadouro, including the one that houses the community telecenter. The group also runs a daycare center, a cultural center, and sports complex. The community is served by one Catholic Church, two Evangelical temples, and one public school where $\mathrm{K}-12$ instruction is available. Fixed line telephony is accessible at three public telephone booths and in a few private homes. At first, the telecenter was the only place with access to broadband Internet. More recently, the government of the state of Minas Gerais installed broadband Internet via satellite in the public school and a local entrepreneur established a privately-operated, for-profit LANhouse with radio-enabled broadband connectivity. The facility offers paid computer and Internet access center to the public and also provides service to select farms in the area.

\section{An Alternative Conceptual Model for Telecenter Evaluation}

Research in the field of information and communication technologies for development (ICT4D) overlaps studies undertaken in the area of community informatics in that both disciplines examine the challenges posed by digital inclusion. Insofar as ICT4D is concerned, much attention is focused in the potential of ICTs to contribute to human development in ways that follow the guidelines proposed under the United Nations Human Development Index and the Millennium Development Goals. Those documents single out and prioritize literacy, education, and digital inclusion as elements essential to the promotion of human development, prosperity and well-being (ITU, 2003; United Nations Development Program [UNDP], 1990). Insofar as telecenters have emerged in 
Latin America as public or commercial spaces that aim to foster digital inclusion, they provide a situated context where the dynamics and processes of ICT adoption and use can be readily examined.

Ever since their inception in the late 1990s, telecenters have been under study by researchers who examine ICT diffusion. In the beginning, these studies for the most part measured the number of telecenter users, hardware and software connectivity, and other material aspects of ICT diffusion without necessarily examining the social change inherent in their adoption. However, early on Avgerou \& Walsham (2000) addressed the importance of examining diffusion from a perspective of how individuals use ICTs within a particular social context. Other scholars amplified this kind of analysis by observing the content produced by ICT users and the social dynamics and communication that occurred in these group settings (Brown \& Duguid, 2002; Schilderman, 2002; Sorj, 2003; Warschauer, 2003a; Wilmore, 2001). All along, a few researchers have looked beyond traditional metrics to consider the impact of ICTs on human development and have found that their diffusion can help under privileged communities benefit from access to the Information Society (Jensen, 2007; Menou, 2001; Roman \& Colle, 2002; Rothenberg-Aalami \& Pal, 2005; Wilson, 2004). The work of Roman (2003), in particular, focused on aspects of diffusion of innovations theory to examine how ICTs are perceived, how their diffusion is communicated, and how they are used. This framework allows for a situated, context-relevant understanding of ICT diffusion that permits for a wider analysis of the ways in which individuals and communities integrate ICTs into their daily lives.

This study proposes an alternative conceptual model for telecenter evaluation which measures the development of digital literacy and other skill sets related to ICT use from a contextually-relevant, self-defined perspective. In doing so, it eschews technologically deterministic metrics that measure effectiveness in terms of numbers of computers in use, individuals trained in software skills, or direct employment resulting from workforce training related to ICT use. The evolution of the model owes to Warschauer's (2003b) recommendation that digital literacy and ICT use be examined within parameters other than the simplistic, performance-based metrics of computer skills. Figure 1 illustrates the proposed model, displaying the dependent variables of ICT use and non ICTrelated use of the telecenter in relation to three sets of predictor variables: structural factors, individual motivation, and demographics. The right side of the model contains categories for telecenter use, listed in accordance with the skill sets involved in their practice; these are: entertainment skills, professional or work skills, civic engagement skills, health and sanitation skills, and literacy. 
Figure 1.

Conceptual Model Relating Structural Factors, Individual Motivation, and Demographics to ICT Use at Gems Telecenters.

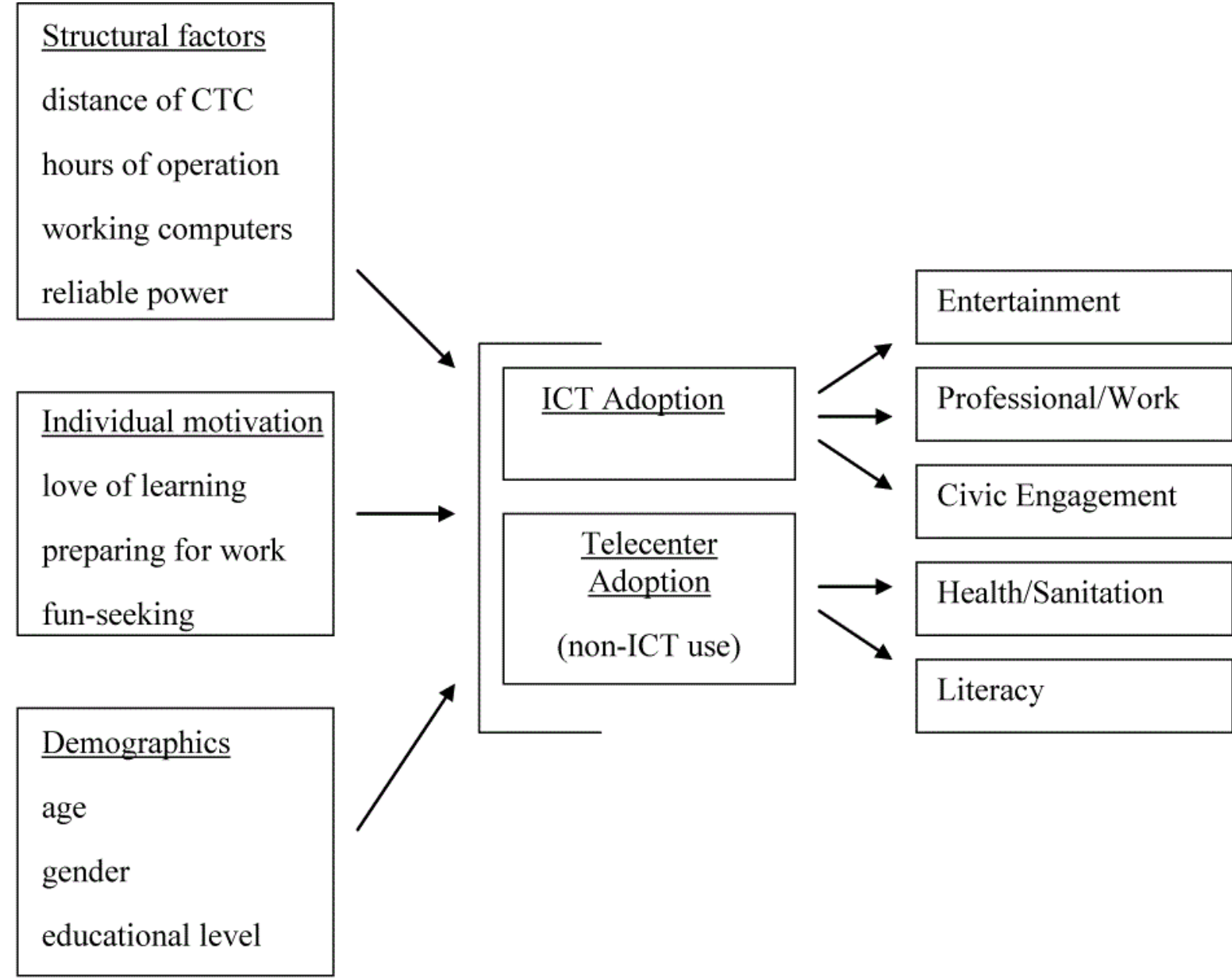

\section{Concepts Considered in the Model}

In order to examine diffusion from a holistic perspective, it is important to take into consideration the impact of several elements, among them: material and structural factors, individual attitude, behavior, and demographic characteristics. The model considers each of these factors in turn, evaluating their impact on the likelihood of ICT adoption at the telecenter.

Firstly, insofar as research focused on ICT diffusion in rural areas is concerned, scholars have identified a particular set of structural factors that impact the rate and effectiveness of adoption. Unlike urban dwellers, rural residents may encounter particular challenges that hinder their access to ICTs. Chief among them is physical access to a telecenter, which can be too far from home or made distant due to precarious road conditions, unreliable or unstable electrical power grids, equipment maintenance, theft, and limited financial resources (Baggio, 2008; Hernandez, Amescua, Rodríguez, \& Alva, 2007; Mori \& Assumpção, 2007; Sorj, 2003).

Secondly, individual attitude and behavior also have been shown to impact ICT adoption. Writing about digital inclusion in Brazil, Sorj (2003) highlighted the 
importance of individual motivation and self esteem as a driver for ICT use. Indeed, Wilson (2004) pinpointed motivation as the single common factor among individuals who are able to overcome structural and personal barriers to ICT adoption.

Furthermore, an individual's ability to understand and appropriate the information accessed through ICTs can impact effective ICT adoption. The quality of one's experience using ICTs is inevitably linked to one's ability to navigate the logic and language of digital processes; these skills may not be available among individuals who are functionally illiterate or live in primarily oral societies (Proenza et al., 2001).

Given the nature of the challenges identified above, this study proposes an alternative conceptual model (see Figure 1) with which to examine factors that predict ICT use. The model proposes that structural factors, individual motivation, and demographics relate to the use of ICTs for purposes of entertainment, civic participation, and professional development. The model also proposes that the availability of a telecenter encourages individuals to obtain information about health, sanitation, agricultural practices, and literacy even when ICTs are not in use. The study thus tests the model to answer the questions:

RQ\#1: To what extent have telecenter users adopted information and communication technologies?

$R Q \# 2$ : What is the relationship between the adoption of information and communication technologies and structural factors that impact access to telecenters?

$R Q \# 3$ : What is the relationship between the adoption of information and communication technologies and individual motivation?

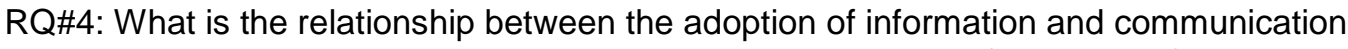
technologies and age, gender, and the educational attainment of individuals?

\section{Method}

The data for this study was collected in a survey of two communities over the course of less than thirty days in April 2010. A purposive sample of two locations was selected from among the five communities where Gems of the Earth established telecenters. The sample, which consisted of the localities of Milho Verde and Tombadouro, mirrored regional demographics and appropriately represented existing variations among telecenter users in the five communities, in the manner recommended by Singleton \& Straits (2005). The a priori criteria guiding sample selection included: (a) participation in the Gems of the Earth NGO, (b) mountainous rural location, and (c) driving distance of one hour to the nearest urban center.

The population sampled consisted of adult men and women residents of Milho Verde and Tombadouro, ages 18 and older. Respondents were drawn from the community at large, not only from among those individuals who had used or visited the telecenters. The Gems of the Earth NGO estimates the population of Milho Verde hovers at about 1,000 and that of Tombadouro at 1,600. These estimates could not be confirmed for the localities given that the Brazilian census publishes data at the level of municipalities; disaggregated population figures at the district level are not readily available.

The principal method of inquiry was a verbally administered survey. The survey method was selected as an appropriate manner to systematically examine social change in 
developing nations at a relatively low cost (Buzzard, 1990). Two local residents (one in each of the communities) were trained by one of the authors in survey procedures prior to administering the questionnaire verbally to a random sample of adults. The data was collected in a manner that preserved the anonymity and confidentiality of individual respondents.

\section{Variables Under Consideration}

The survey captured three levels of independent variables. The first category consisted of descriptive data regarding self reported use of ICTs at the telecenter (defined as use of computer for purposes of instruction, school work, professional or personal reasons, Internet surfing, chatting, music and video downloads, access to news and e-mail, and contact with government agencies). The second was comprised of perceived structural factors that facilitate or hinder telecenter access (defined as distance from home, convenient hours of operation, hardware and software operation, and consistent electrical power). The third measured individual motivation for the use of ICTs (defined as love of learning, professional improvement, and entertainment purposes).

The data were entered into SPSS Statistics 17.0 for Windows. The data was computed into indices of ICT use, allowing for the calculation of the odds ratio of the three skill sets contained in the proposed model (see Figure 1) that require digital literacy. The indices, which indicated how respondents used ICTs, categorized use according to five primary areas of activity: (a) entertainment (defined as use of a personal nature, including chatting, downloading music or videos); (b) civic engagement (defined as accessing news sources or government information, as well as contacting governmental agencies); and (c) professional reasons (defined as work-related uses, including the development of professional skills and e-mail access). Two additional measures were computed to account for the activities of respondents who did not use ICTs yet visited the telecenter. These included a health index (defined as access to information about personal or family health care, water preservation and sanitation practices, or instruction on the care of crops and farm animals) and a literacy indicator (defined as learning to read or write at the telecenter).

The data were analyzed using multivariate logistic regression to gauge the odds of each of the independent variables related to structural factors, individual motivation, and demographics in predicting ICT adoption and user habits at the telecenters. Logistic regression was selected because it is an appropriate method to model odds ratio (Demaris, 1995). Descriptive statistics elicited comparison of variables that measured the perceived impact of the telecenter in the community.

\section{Results}

Descriptive statistics presented in Table 1 outline sample demographics: respondents consisted of 538 male and female adults 18 years of age and older in the communities of Milho Verde $(n=236)$ and Tombadouro $(n=302)$. The sample consisted of 289 women (53.8\%) and 248 men (46.2\%), almost half of whom (40.6\%) had only completed lower school. 
Table 1.

Sample Demographics

Milho Verde $\quad \underline{\text { Tombadouro }} \underline{\text { Totals }}$

\section{Demographics}

Male

Female

$\underline{\text { Age }}$

18-24 years of age

25-35 years of age

35 or more years of age
$126(53.4 \%)$

$110(46.6 \%)$

$62(26.3 \%)$

$33(14 \%)$

$140(59.3 \%)$

$\underline{\text { Educational level }}$

College/University

High school

Elementary

Incomplete elementary
$21(8.9 \%)$

$74(31.4 \%)$

$83(35.2 \%)$

$58(24.6 \%)$
$122(40.5 \%)$

$248(46.2 \%)$

$179(59.5 \%)$

$289(53.8 \%)$

$180(33.5 \%)$

$118(21.9 \%)$

$237(44.1 \%)$

$97(32.1 \%)$

$55(10.2 \%)$

$217(40.3 \%)$

$143(47.8 \%)$

$149(27.7 \%)$

$66(22.1 \%)$

$56(18.7 \%)$

$114(21.2 \%)$

$\mathrm{N}=538$

One out of $10(10.2 \%)$ held a college degree and, 217 (40.3\%) completed high school, and $114(21.2 \%)$ did not finish lower school. The slightly higher than average proportion of college-educated individuals is consistent with a representative sample of telecenter users, who tend to skew higher for educational achievement than the population in the community as a whole.

The mean age was 35; the youngest respondent was 18 years of age and the eldest 79. Two hundred thirty seven (44.1\%) respondents were age 35 or older, with a noticeable skew in Milho Verde, where 140 (59.3\%) of the sample belonged in the older age bracket. There were 180 (33.5\%) respondents between the ages of 18 and 24 , and $118(21.9 \%)$ between the ages of 25 and 34 . 
Table 2.

Structural Variables and Individual Motivation

Milho Verde $\quad \underline{\text { Tombadouro }} \underline{\text { Totals }}$

$\underline{\text { Structural factors }}$

Distance (nearby)

$177(90.8 \%)$

$222(85.4 \%)$

$399(87.7 \%)$

Convenient hours

$72(41.1 \%)$

$285(96.6 \%)$

$357(76 \%)$

Computers work well

$171(95 \%)$

$277(97.2 \%)$

$448(96.3 \%)$

Consistent electrical power 144 (85.2\%)

$300(100 \%)$

$444(94.7 \%)$

$\underline{\text { Individual Motivation }}$

$\begin{array}{llll}\text { Love of learning } & 65(27.5 \%) & 268(88.7 \%) & 333(62.9 \%) \\ \text { Preparing for work } & 63(26.7 \%) & 255(84.4 \%) & 318(59.1 \%) \\ \text { Fun-seeking } & 48(20.3 \%) & 227(75.2 \%) & 275(51.1 \%)\end{array}$

$\mathrm{N}=538$

\section{Structural Factors and Individual Motivation Predictors}

As for predictor variables regarding structural factors that impact access and individual motivation to visit the telecenter, descriptive results listed in Table 2 indicate that respondents enjoyed easy access to the telecenter and that computers operated well, and that the power supply was mostly reliable. The lone exception was in Milho Verde, where $72(41.1 \%)$ respondents indicated that telecenter operating hours were not convenient. Insofar as individual motivation for telecenter use, individuals reported a love of learning $(62.9 \%)$ and preparing for work $(59.1 \%)$ as their main motivation, more often than diversion or fun-seeking $(51.1 \%)$. There was no significant difference reported in the motivation of respondents at either location. 
Table 3.

Descriptive Statistics of ICT Use and Non-ICT Use of Telecenter

Milho Verde $\quad \underline{\text { Tombadouro }} \underline{\text { Totals }}$

ICT Adoption

\begin{tabular}{lllr} 
ICT users at telecenter & \multicolumn{1}{c}{$57(24.2 \%)$} & $184(60.9 \%)$ & $241(44.8 \%)$ \\
Non-ICT users at telecenter & $179(75.4 \%)$ & $118(39.1 \%)$ & $297(55.2 \%)$ \\
Skills used & & & \\
Entertainment & $49(20.8 \%)$ & $159(52.6 \%)$ & $208(38.7 \%)$ \\
Professional/work skills & $38(16.1 \%)$ & $175(57.9 \%)$ & $213(39.6 \%)$ \\
Civic Engagement & $48(20.3 \%)$ & $163(54 \%)$ & $211(39.2 \%)$ \\
Health/Sanitation & $24(10.2 \%)$ & $80(26.5 \%)$ & $104(19.4 \%)$ \\
Literacy & $2(8 \%)$ & $57(18.9 \%)$ & $59(11 \%)$ \\
\hline \multicolumn{1}{c}{$\mathrm{N}=538$} & & & \\
\hline
\end{tabular}

\section{ICT Users at Gems of the Earth Communities}

In regard to the use of the telecenter, descriptive results presented in Table 3 show that the number of respondents who visited the telecenters at least once in the 30 days prior to the survey $(44.8 \%)$ was slightly lower than that of those who had not been there during that time $(55.2 \%)$. Two hundred thirty six $(44 \%)$ respondents had visited at least five and at most 10 times during that period, and 154 respondents (28.7\%) used the telecenter at least once and as much as five times during the same period. Two hundred ninety-six $(55 \%)$ respondents stated that they either never visited the telecenter or did so infrequently.

The 241 respondents (44.8\%) who stated that they had used ICTs at the telecenters were categorized as ICT users. Overall, 108 respondents (20.1\%) stated they used ICTs for reasons related to work, $84(15.6 \%)$ reported using them for school work, and $131(24.3 \%)$ indicated that they used them for personal reasons. Not all users accessed the Internet when at the telecenter; among the 190 (35.4\%) who did, 33 used it to chat online. Descriptive results presented in Table 3 show that the use of ICTs was distributed evenly among three categories detailed in the model: 208 (38.7\%) used ICTs for entertainment, $213(39.6 \%)$ used ICTs for professional or work-related pursuits and $211(39.2 \%)$ used ICTs to participate in civic life. Those who did not use ICTs at the telecenter (30.3\%) nevertheless practiced other skills while there: 104 (19.4\%) learned about health care, sanitation, or how to tend to their crops and animals. Fifty- 
nine individuals (11\%) indicated that they had learned how to read and write at the telecenter. The vast majority of the latter were in Tombadouro.

\section{Predictors of ICT Use}

A multivariate logistic regression tested model fit and predicted the various relationships contained in the proposed conceptual model (Figure 1). Tables 4.1 through 4.6 present odd ratios for the corresponding variables, highlighting unstandardized regression coefficients with probabilities of $p<.10, p<.05$ and $p<.01$.

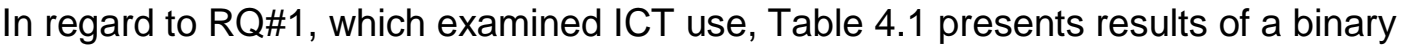
logistic regression that show higher odds for individuals who are more educated or are motivated to seek fun to use ICTs $(p<.01)$. The same Table indicates smaller odds for individuals over the age of 25 to use ICTs, as compared to those ages 18 through 24 . In addition, results in model one show that more convenient hours of operation increase the odds of ICT use $(p<.01)$. Results in model two indicate greater odds that individuals motivated to improve their professional skills will use ICTs $(p<.05)$.

\section{Predictors of Skills Used}

In regard to $R Q \# 2$, none of the variables related to structural factors (distance from home, convenient hours of operation, hardware and software operation, and consistent electrical power) emerged as a predictor for the practice of entertainment, civic engagement, or professional skills. They also did not emerge as predictors for the practice of health and sanitation or literacy skills. Still, model one in Tables 4.2, 4.3, 4.4 indicates that convenient hours of operation increase the odds that individuals practice entertainment, civic engagement, or professional skills $(p<.01)$, or health, sanitation, and literacy skills $(p<.05)$, as shown in Tables 4.5 and 4.6 .

In regard to $R Q \# 3$, which examined individual motivation in ICT use, results presented in Tables 4.2, 4.3, 4.4 show increased odds that individuals motivated to have fun will practice the use of ICTs for purposes of entertainment, civic engagement, or professional skills $(p<.01)$. The motivation to have fun also increased the odds that individuals would seek information regarding health, sanitation, and the care of animals and crops at the telecenter $(\mathrm{p}<.05)$. 
Table 4.1

Binary Logistic Regression of ICT Use

Model 3

Model 1

Model 2

\begin{tabular}{|c|c|c|c|c|c|c|c|c|c|c|c|c|}
\hline & $b$ & SE & OR & $B$ & SE & OR & $b$ & SE & OR & $b$ & SE & OR \\
\hline \multicolumn{13}{|l|}{$\frac{\text { Structural }}{\text { factors }}$} \\
\hline & 0.52 & 0.3 & 1.6 & & & & & & & - & 0.5 & \\
\hline Distance & 6 & 41 & 92 & & & & & & & 0.250 & 04 & 0.779 \\
\hline Hours of & 1.42 & 0.3 & 4.1 & & & & & & & & 0.5 & \\
\hline operation & $5^{\star \star *}$ & 29 & 58 & & & & & & & 0.165 & 15 & 1.180 \\
\hline Working & 0.00 & 0.6 & 1.0 & & & & & & & & 0.9 & \\
\hline computers & $\begin{array}{l}3 \\
-\end{array}$ & 34 & 03 & & & & & & & 0.263 & 98 & 1.300 \\
\hline $\begin{array}{l}\text { Electrical } \\
\text { power } \\
\text { Individual } \\
\text { Motivation } \\
\end{array}$ & $\begin{array}{c}0.56 \\
6\end{array}$ & $\begin{array}{l}0.6 \\
65\end{array}$ & $\begin{array}{l}0.5 \\
68\end{array}$ & & & & & & & $0.701^{-}$ & $\begin{array}{r}0.9 \\
88\end{array}$ & 0.496 \\
\hline Love of & & & & 0.50 & 0.6 & & & & & - & 0.7 & \\
\hline learning & & & & & 13 & 0.605 & & & & 0.548 & 35 & 0.578 \\
\hline Preparing for & & & & 1.23 & 0.5 & & & & & & 0.7 & \\
\hline work & & & & $9^{\star *}$ & 64 & 3.452 & & & & 0.905 & 98 & 2.472 \\
\hline & & & & 2.27 & 0.4 & & & & & 2.344 & 0.6 & \\
\hline $\begin{array}{l}\text { Fun-seeking } \\
\text { Demographi }\end{array}$ & & & & $6^{* \star *}$ & 54 & 9.740 & & & & $* * *$ & 25 & 10.418 \\
\hline$\underline{\underline{C S}}$ & & & & & & & & & & & & \\
\hline Female & & & & & & & 0.344 & $\begin{array}{l}0.1 \\
95\end{array}$ & 1.410 & $0.529^{-}$ & $\begin{array}{r}0.3 \\
26\end{array}$ & 1.698 \\
\hline & & & & & & & $1.118^{-}$ & 0.2 & & $1.394^{-}$ & 0.4 & \\
\hline Ages 25-34 & & & & & & & $* * *$ & 61 & 0.327 & ** & 11 & 0.248 \\
\hline $\begin{array}{l}\text { Ages } 35 \text { and } \\
\text { older }\end{array}$ & & & & & & & $\begin{array}{r}1.818 \\
* *\end{array}$ & $\begin{array}{l}0.7 \\
46\end{array}$ & 0.162 & 1.202 & $\begin{array}{r}0.3 \\
82\end{array}$ & 0.301 \\
\hline Order & & & & & & & 0.686 & 0.1 & 0.100 & 0.730 & 0.1 & 0.001 \\
\hline $\begin{array}{l}\text { Education } \\
\text { Model } \\
\text { Statistics }\end{array}$ & & & & & & & $\star * *$ & 15 & 1.986 & $\star * *$ & 72 & 2.075 \\
\hline & & & 3.2 & & & 136.17 & & & 115.78 & & & 120.04 \\
\hline Model $X^{2}$ & & & 22 & & & $7^{\star \star \star}$ & & & $7^{\star \star \star}$ & & & $0^{\star \star * *}$ \\
\hline Nagelkerke & & & 0.0 & & & & & & & & & \\
\hline $\mathrm{R}$ & & & 66 & & & 0.384 & & & 0.260 & & & 0.471 \\
\hline
\end{tabular}

${ }^{*} p<.10 ;{ }^{* *} p<.05 ;{ }^{* *} p<.01$. Note: Unstandardized binary logistic regression coefficients $(\mathrm{b})$, standard error (SE), and odds ratio. 
Table 4.2

Binary Logistic Regression of Entertainment Skills

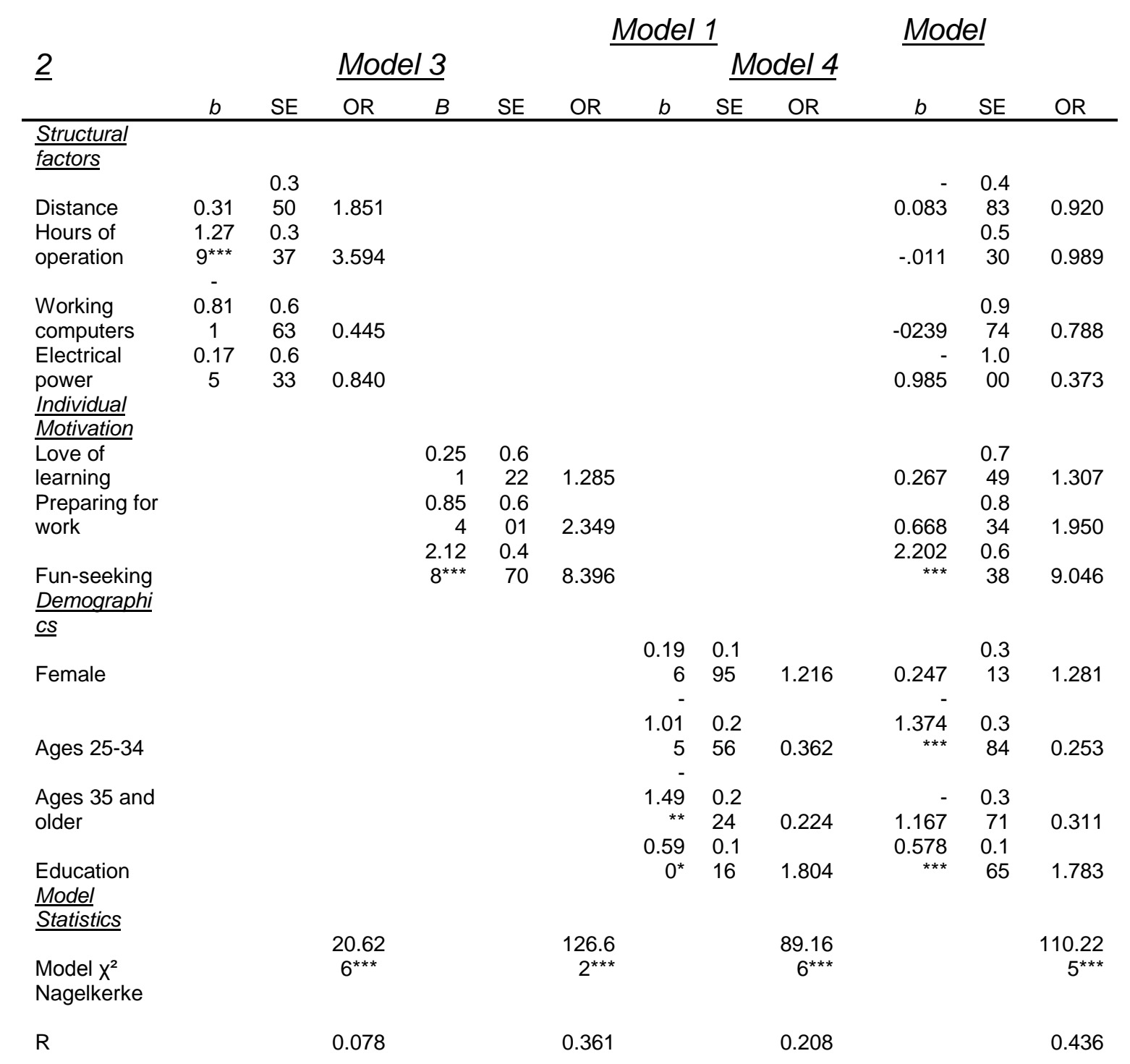

${ }^{\star} p<.10 ;{ }^{* \star} p<.05 ;{ }^{* *} p<.01$. Note: Unstandardized binary logistic regression coefficients (b), standard error (SE), and odds ratio. 
Table 4.3

Binary Logistic Regression of Civic Engagement Skills

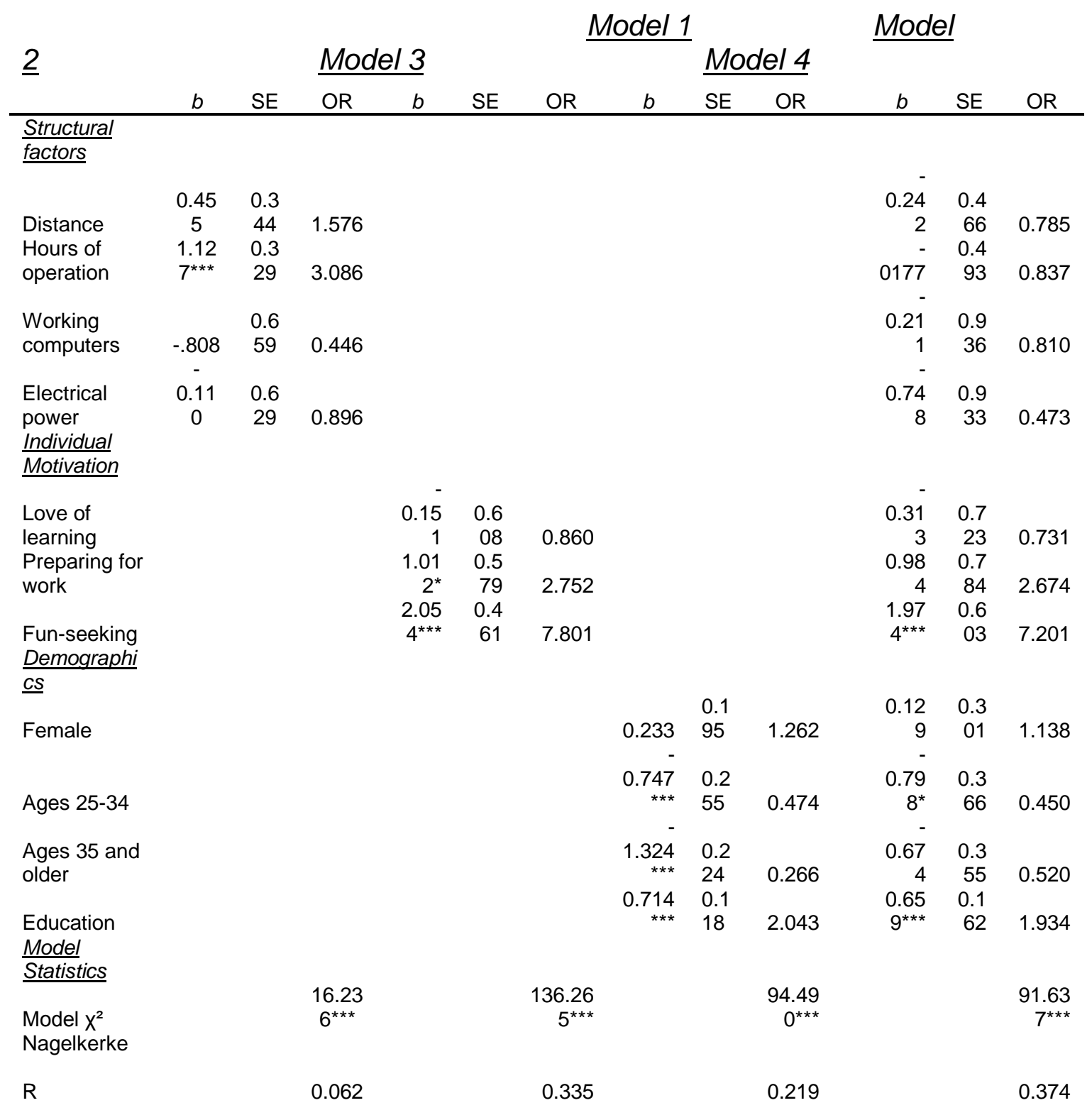

${ }^{\star} p<.10 ;{ }^{* *} p<.05 ;{ }^{* * *} p<.01$. Note: Unstandardized binary logistic regression coefficients (b), standard error (SE), and odds ratio. 
Table 4.4

Binary Logistic Regression of Professional Skills

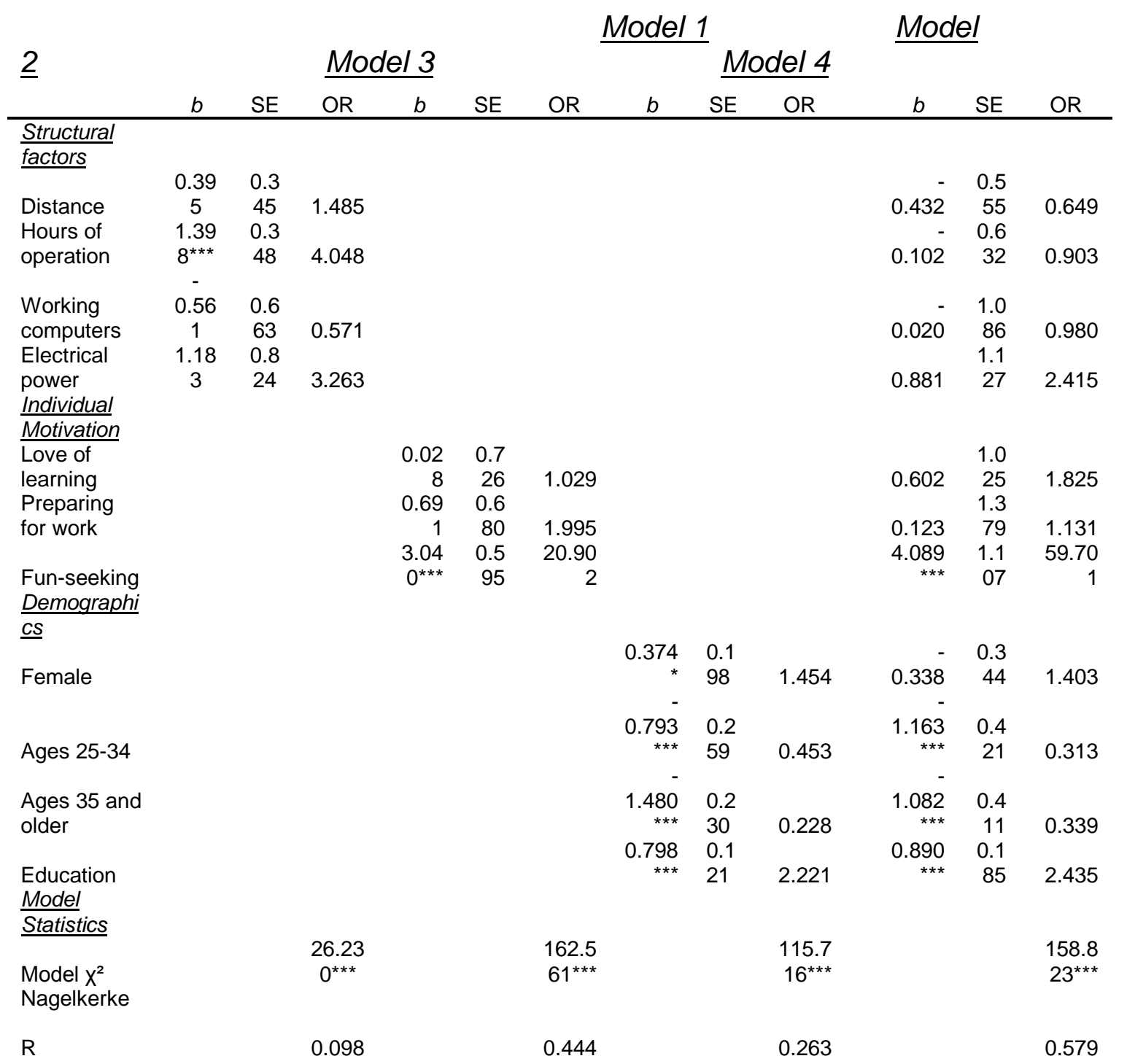

${ }^{\star} p<.10 ;{ }^{* *} p<.05 ;{ }^{* * *} p<.01$. Note: Unstandardized binary logistic regression coefficients (b), standard error (SE), and odds ratio. 
Table 4.5

Binary Logistic Regression of Health and Sanitation Skills

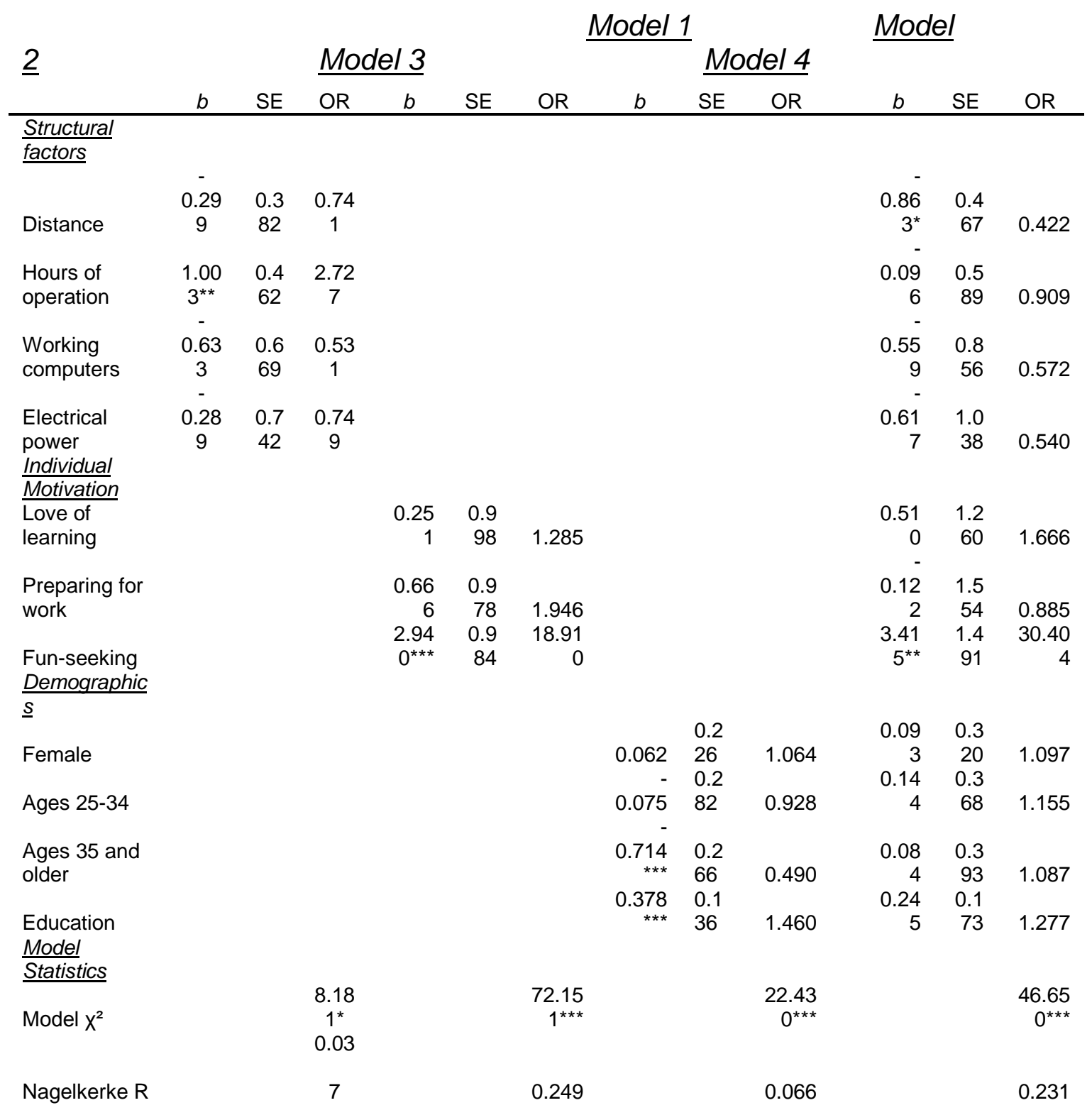

${ }^{\star} p<.10 ;{ }^{* \star} p<.05 ;{ }^{* *} p<.01$. Note: Unstandardized binary logistic regression coefficients (b), standard error (SE), and odds ratio. 
Table 4.6

Binary Logistic Regression of Literacy Skills

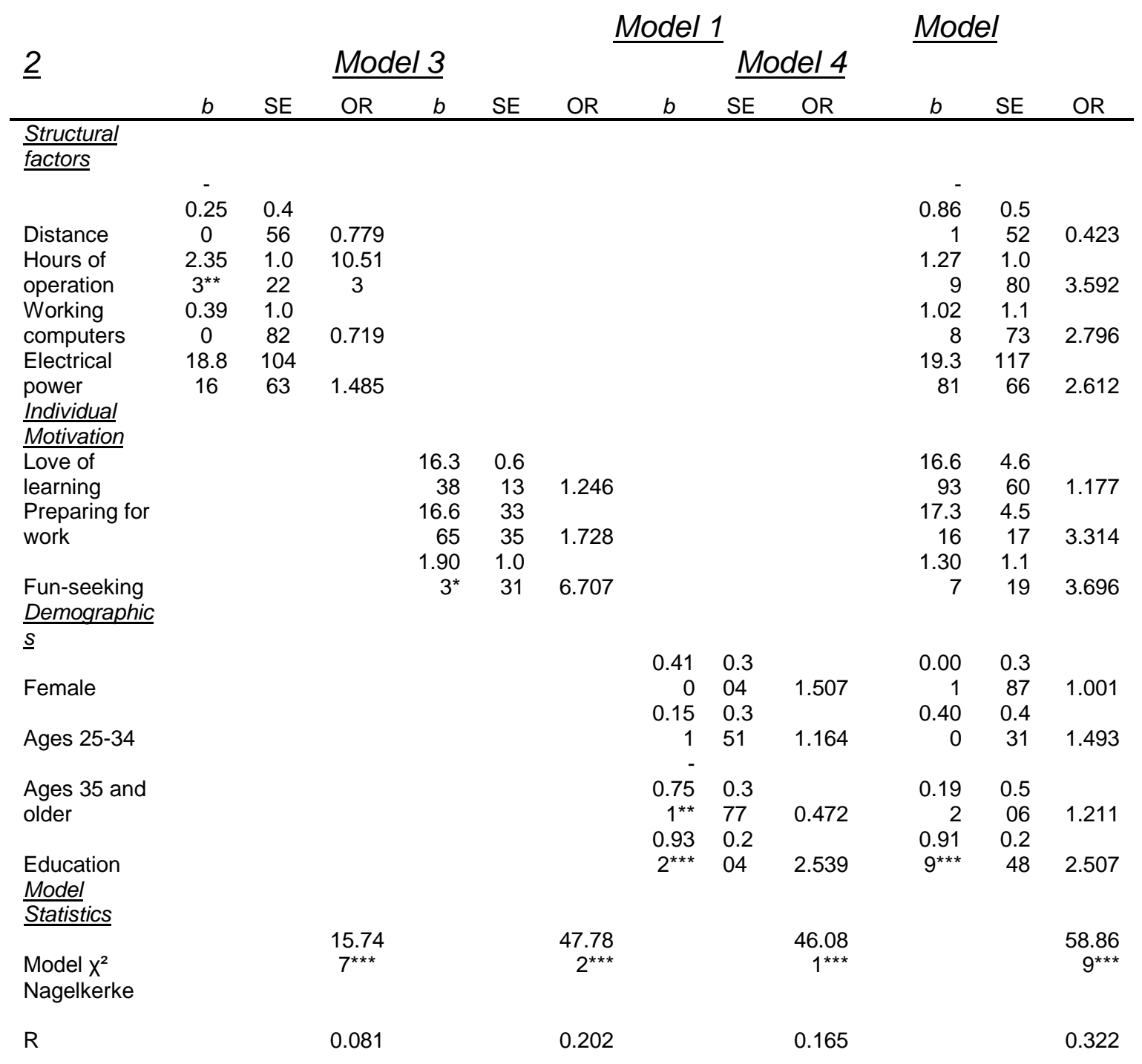

${ }^{*} p<.10 ;{ }^{* *} p<.05 ;{ }^{* * *} p<.01$. Note: Unstandardized binary logistic regression coefficients (b), standard error (SE), and odds ratio. 
Next, in regard to $R Q \# 4$, results presented in Tables 4.2, 4.3, and 4.4 show demographic factors of age and educational attainment emerged as predictors of the use of ICTs for entertainment, civic engagement, or professional skills. As seen in Table 4.2, there are smaller odds that individuals over the age of 25 will use ICTs for entertainment $(p<.01)$, although the model also indicates increased odds that those who are more educated will do so $(p<.01)$. Results in Table 4.3 likewise show smaller odds that those between 25 and 34 years of age would use ICTs to access news and information about government services or agencies $(p<.10)$ or to practice professional skills $(p<.01)$, as reported in Table 4.4. Indeed, results presented in Table 4.4 show smaller odds that those over the age of 25 would use ICTs to learn or improve their work skills. On the other hand, the same Table presents results that show increased odds that better educated individuals would use ICTs to acquire or practice work skills. Finally, in regard to the use of telecenters for purposes not related to ICTs, results presented in Table 4.6 show a single predictor emerged, indicating increased odds that those who gained in educational attainment learned to read and write at the telecenter.

\section{Telecenter Impact on Digital Inclusion}

Almost half $(45 \%)$ of the people surveyed in the two communities used ICTs at the telecenter in the 30 days prior to the data collection for this study. Their use of ICTs was evenly distributed for purposes of entertainment, civic engagement, and the development of professional skills. The motivation to enjoy oneself and have fun emerged as a predictor of ICT use for entertainment, civic engagement, and workrelated practices. Previous research by Perse \& Dunne (1998) indicated that computers are considered useful media that satisfy needs of entertainment, diversion, and escapism, as well as a pastime and a regular habit. The findings in the present study confirm that the drive to enjoy oneself is central to one's engagement with ICTs.

Other findings in this study support the consensus in the literature that points to decreased odds that individuals older than 25 years of age will use ICTs. Equally important are the findings that there are greater odds that individuals who are better educated will use ICTs. The latter can be understood as a beneficial impact insofar as ICT diffusion supports education and the practice of digital literacy, among other skills. However, Heeks \& León (2009), among others, have expressed concern that the diffusion of ICTs in rural areas may perpetuate existing patterns of social inequality by privileging some and not all members of a community.

Last but not least, descriptive results show that more than ten percent of individuals in the community learned to read and write at the telecenter. Adult literacy, which emerged in this study as a predictor for educational attainment, has been identified by the United Nations Development Program (1990) as a key educational factor for human development, and as such is one of the criteria included in the organization's Human Development Index. This study has shown that beyond the practice of digital literacy, telecenters can be effective tools that foster human development by extending access to varied types of information to marginalized communities.

It is important to note that while the survey method used in this study provides an efficient tool for capturing data from large samples of respondents in a systematic manner, it holds inherent limitations. Self-reported data may contain inaccuracies that 
stem from failure of memory, lack of candor, reluctance to answer correctly, and thus is seldom completely free of error (Singleton \& Straits, 2005). Furthermore, a limitation particular to the examination of ICT habits is that respondents commonly overlap work and entertainment use, making it difficult for researchers to reliably distinguish the time spent on different pursuits. The survey protocol used in this study attempted to address these limitations inasmuch as possible by incorporating questions that allowed researchers to contrast and compare user habits and self-reported motivation.

\section{Conclusions}

This study found increased odds that individuals will practice ICT use when telecenters are accessible at convenient times of day and offer a source of entertainment. Whereas the proposed model did not find that other structural or motivational factors predict ICT use, it confirmed previous studies that predict increased odds of ICT use among better educated individuals under the age of 25 . Finally, this study offers evidence that the pioneering Gems of the Earth initiative has, in less than a decade, increased digital literacy in the communities it serves. Insofar as this meets the key benchmark of digital inclusion outlined in the Millennium Development Goals, it indicates that the telecenter network offers an effective model for social change.

In light of the Brazilian government's embrace of a policy to expand the telecenter initiative nationwide, it becomes increasingly important to assess how pioneer telecenters impacted the communities they served, so that future researchers may compare and contrast newly created ICT access against the benchmark of early projects. Further research is needed to gauge the extent to which enhanced connectivity adds new knowledge, improves professional skills, positively impacts agricultural production, and strengthens social ties to the outside world.

In a discipline which often resorts to situated methodologies the nature of which precludes generalization, there is limited evidence about the ways in which telecenter projects in remote locations may contribute to communal prosperity. In analyzing some of the ramifications of digital inclusion initiatives in the mountains of Brazil, this study sought to amplify in a holistic manner the way in which the discipline examines telecenter projects in the developing world. Scholars would do well to further research the issue without prejudice to the varied ways in which individuals choose to practice digital literacy. 


\section{References}

Amariles, F., Paz, O. P., Russell, N., \& Johnson, N. (2006). The impacts of community telecenters in rural Colombia. Journal of Community Informatics 2(3). http://cijournal.net/index.php/ciej/issue/view/15

Avgerou, C., \& Walsham, G. (Eds.). (2000). Information technology in context: Studies from the perspective of developing countries. London: Ashgate.

Baggio, R. (2008). Nosso trabalho. [Our work]. Committee for Democratization of Information Technology (CDI). Retrieved March 18, 2008 from www.cdi.org.br

Bossio, J. F. (2006). Social sustainability of telecenters from the viewpoint of operators: A case study from São Paulo. Unpublished doctoral dissertation, London School of Economics, London, England.

Brown, J. S., \& Duguid, P. (2002). The social life of information. Boston: Harvard Business School.

de Moor, A. (2009). Moving Community Informatics Research Forward. Journal of Community Informatics, 5(1). http://ci-journal.net/index.php/ciej/article/view/546

DeMaris, A. (1995). A tutorial in logistic regression. Journal of Marriage and the Family $57,956-968$.

Eastin, M. S., \& LaRose, R. (2000). Internet self-efficacy and the psychology of the digital divide. Journal of Computer-Mediated Communication, 6(1), 0-0.

Figueiredo, M.; Camara, M.; \& Sabin, R. (2006). Impact of the insertion of modern information and communication technologies in Brazilian rural communities. Columbia, MD: Loyola College.

Figueiredo, M. (2005). Gems of the Earth Guide to Rural Community Telecenters. Retrieved from http://www.gemasdaterra.org.br/modules.php?name=Downloads\&d op=viewdownload \&cid $=4$

Granqvist, M. (2005). Looking critically at ICT4Dev: The case of Lincos. The Journal of Community Informatics, 1(2), 21-34. http://ci-journal.net/index.php/ciej/article/view/265

Gumucio-Dagron, A. (2003, December 11). What can ICTs do for the rural poor? Paper presented at the World Summit for the Information Society, Geneva, Switzerland.

Gurstein, M. (2003). Effective use: A community informatics strategy beyond the digital divide. First Monday, 8 (2).

http://firstmonday.org/htbin/cgiwrap/bin/ojs/index.php/fm/article/view/1107/1027

Heeks, R., \& León K., L. (2009). Remoteness, exclusion and telecentres in mountain regions: Analysing ICT-based "information chains" in Pazos, Peru. Working Paper Series, Paper No. 38. Development Informatics Group. Institute for Development Policy 
and Management. Manchester, United Kingdom: University of Manchester. http://www.itu.int/wsis/docs/geneva/official/poa.html

Hernandez, L. H. P., Amescua, B. S., Rodríguez, J. M. R., \& Alva, M. G. H. (2007). Sujetos y contextos locales: La piedra angular en la implementación de las políticas de inclusión digital [Subjects and local contexts: The cornerstone of the implementation of digital inclusión policies]. The Journal of Community Informatics 3(3).

International Telecommunications Union [ITU]. (2003). World Summit on the Information Society. Retrieved June 1, 2009 from Khelladi, Y. (2001). What works: The infocentros telecenter model. World Resources Institute. World Resources Institute. Retrieved May 12, 2008, from http://www.digitaldividend.org

International Telecommunications Union [ITU]. (2010). ITU ICT Eye: Brazil. Retrieved May 5, 2010, from http://www.itu.int/lTU-D/icteye/DisplayCountry.aspx?countryld=27

Jensen, R. (2007). The digital provide: Information (technology), market performance and welfar in the South Indian fisheries sector. Quarterly Journal of Economics, 122(3), 879-924.

Menou, M. (2001). IsICTometrics: Toward an alternative vision and process. Retrieved May 12, 2008, from http://funredes.org

Mori, C. K. \& Assumpção, R. O. (2007). Brazilian digital inclusion public policy: Achievements and challenges. Journal of Community Informatics, 3(3). http://cijournal.net/index.php/ciej/article/view/424

Norris, P. (2001). Digital divide: Civic engagement, information poverty, and the Internet worldwide. NY: Cambridge University Press.

Parkinson, S., \& Lauzon, A. (2008). The impact of the Internet on local social equity: A study of a telecenter in Aguablanca, Colombia. Information Technologies and International Development 4(3), 21-38

Parkinson, S., \& Ramirez, R. (2006). Using a sustainable livelihoods approach to assessing the impact of ICTs in development. Journal of Community Informatics 2(3). http://ci-journal.net/index.php/ciej/article/view/310

Perse, E. M. \& Dunn, D. G. (Fall 1998). The Utility of home computers and media use: Implications of multimedia and connectivity. Journal of Broadcasting and Electronic Media, 42.4435.

Prado, P. (2009). Bridging digital poverty: Adoption of information and communication technologies at community technology centers in the Dominican Republic. Doctoral dissertation. Coral Gables, FL: University of Miami.

Proenza, F. J., Bastidas-Buch, R., \& Montero, G. (2001, May). Telecenters for socioeconomic and Rural Development in Latin America and the Caribbean: Investment opportunities and design recommendations, with special reference to Central America. Washington, DC: Inter-American Development Bank. 
Robertson, S. (1998). Telecenters in Mexico: Learning the hard way. Journal of Development Communication 9(2).

Roman, R. (2003). Diffusion of innovations as a theoretical framework for telecenters. Information Technologies and International Development, 1(2), 55-68.Roman, R., \& Colle, R. D. (2002, July). Creating a participatory telecenter enterprise. Paper presented at the Participatory Communication Research Section in the annual meeting of International Association for Media and Communication Research, Barcelona, Spain.

Rothenberg-Aalami, J., \& Pal, J. (2005, January). Rural telecenter impact assessments and the political economy of ICT of development. Berkeley Roundtable on the International Economy Working Paper 164. Berkeley, CA: University of California.

Schilderman, T. (2002). Strengthening the knowledge and information systems of the urban poor. Practical Action, ITDG. Retrieved December 10, 2008, from http://www.eldis.org/cf/search/disp/docdisplay.cfm?doc=DOC10072\&resource=f1

Servon, L. J. (2002). Bridging the digital divide: Technology, community, and public policy. Malden, MA: Blackwell.

Singleton, R., \& Straits, B.C. (2005). Approaches to social research. NY: Oxford University.

Sorj, B. (2001, October). www.vivafavela.com.br: Fighting the urban digital divide. Latin American technological information network. Retrieved April 4, 2009 from http://www.ritla.net/index.php?option=com content\&task=blogcategory\&id=86\&ltemid= $\underline{271 \text { \&limit }=9 \text { \&limitstart }=27}$

Sorj, B. (2003).Brasil@povo.com: A luta contra a desigualdade na sociedade da informação [Brasil@povo.com: The struggle against inequality in the Information Society]. Rio de Janeiro: J. Zahar.

Singleton, R., \& Straits, B.C. (2005). Approaches to social research. New York, NY: Oxford University.

United Nations Development Program [UNDP]. (1990). Human Development Report 1990. Retrieved May 4, 2010, from http://hdr.undp.org/en/reports/global/hdr1990/

Vallejo Montoya, E. (2007). Telecentros comunitarios: Un espacio para la participación y formación ciudadana. La experiencia de Manizales, Colombia [Community telecenters: A space for participation and citizenship formation. The Manizales experience]. Journal of Community Informatics 3(3).

Warschauer, M. (2003). Social capital and access. Universal Access in the Information Society, 2(4), 315-330.

Warschauer, M. (2003). Technology and social inclusion: Rethinking the digital divide. Cambridge, Mass.: MIT Press.

Whyte, A. (1999). Understanding the role of community telecentres in development: A proposed approach to evaluation. In Gomez R. and Hunt P. (Eds.), Telecentre 
evaluation: A global perspective, report of an international meeting on telecentre evaluation. Ottawa: International Development Research Centre [IDRC].

Whyte, A. (2000). Assessing community telecentres: Guidelines for researchers. Ottawa: International Development Research Centre.

Wilmore, D. (2001). Establishing a community of learners: The use of information technology (IT) as an effective learning tool in rural primary or elementary schools. Retrieved May 15, 2008, from http://ifets.ieee.org/periodical/vol 3 2001/discuss summary april2001.html

Wilson, E. J., III (2004). The information revolution and developing countries. Cambridge, MA: MIT.

\section{Endnotes}

[1] The authors wish to thank Eva Maria Pinto, Thomas Kuberek, and Gildete Ribeiro for their contribution to this study.

[2] Mineiro. The term refers to anyone or anything originating in the state of Minas Gerais.

[3] Estrada Real. Established late in the seventeenth century, the Royal Road allowed for the gold, diamonds, and other gems to flow from the mining region surrounding Vila Rica (now known as Ouro Preto) to the port of Paraty, in the vicinity of Rio de Janeiro, from where they were shipped to Lisbon, capital of the Portuguese empire. 